\title{
Literatura e cultura do entretenimento: padrões de consumo entre jovens
}

Tatiana Prevedello ${ }^{1}$

\begin{abstract}
Resumo:
Na sociedade contemporânea a relação entre literatura, cultura, mercado e entretenimento é bastante tênue. Diante destes elementos, a presente pesquisa objetivou investigar, entre o público juvenil de um Instituto Federal, seus comportamentos de consumo mediados pela influência literária. Walter Benjamin (1994) compreende que o objeto artístico e a literatura podem ser pensados como mercadorias que chegam ao público, passíveis de ser compradas e consumidas por muitos. Para Canclini (2008), os grandes fenômenos literários destinados ao consumo em escala global foram originados da influência capitalista em seus desdobramentos sociais e políticos e, também, auxiliam na dinâmica desses mesmos processos, ultrapassando o nicho literário. Buscou-se, assim, mapear, entre os jovens participantes, hábitos literários e culturais relacionados ao mercado e ao entretenimento. Para tanto foi utilizado o suporte teórico-metodológico, aliado à pesquisa de campo, com o propósito de estudar a relação que os jovens integrantes da pesquisa estabelecem com a literatura destinada ao consumo em grande escala e mediada pela indústria cultural. Verificou-se, por intermédio de um questionário autoaplicável, a situação socioeconômica dos alunos investigados, padrões de consumo e, de que maneira, a literatura com amplo alcance midiático tem exercido influência sobre o comportamento dos jovens em suas decisões de compra e entretenimento.
\end{abstract}

\section{Palavras-chave:}

Literatura. Jovens. Consumo. Mercado. Entretenimento.

\section{Literature and entertainment culture: consumption patterns among young people}

Abstract: In contemporary society the relationship between literature, culture, market and entertainment is quite tenuous. Faced with these elements, the present research aimed to investigate, among the youth audience of a Federal Institute, their consumption behavior mediated by literary influence. Walter Benjamin (1994) understands that the artistic object and literature can be thought of as products that reach the public, which can be bought and consumed by many. For Canclini (2008), the great literary phenomena destined for consumption on a global scale were originated from the capitalist influence in their social and political developments and, also, help in the dynamics of these

1 Doutora em Letras - Estudos de Literatura pela UFRGS. Professora EBTT-CMPA. E-mail: t_prevedello@hotmail.com. ORCID iD: http://orcid.org/0000-0002-5742-7692. 
same processes, going beyond the literary niche. Literary and cultural habits related to the market and entertainment among the young participants were mapped. Theoretical-methodological support was used, in conjunction with the field research, in order to study the relationship that the young members of the research establish with the literature intended for consumption on a large scale and mediated by the cultural industry. It was verified through a self-administered questionnaire, the socioeconomic situation of the investigated students, consumption patterns and, in a way, the literature with wide media reach has an influence on the youngsters' behavior in their purchase and entertainment decisions.

Keywords: Literature. Young. Consumption. Marketplace. Entertainment.

\title{
Literatura y cultura del entretenimento: patrones de consumo entre los jóvenes
}

\begin{abstract}
Resumen: En la sociedad contemporánea la relación entre literatura, cultura, mercado y entretenimiento es bastante tenue. En vista de estos elementos, la presente investigación tuvo como objetivo investigar, entre la audiencia juvenil de un Instituto Federal, su comportamiento de consumo mediado por la influencia literaria. Walter Benjamin (1994) entiende que el objeto artístico y la literatura pueden concebirse como bienes que Ilegan al público, que pueden ser comprados y consumidos por muchos. Para Canclini (2008), los grandes fenómenos literarios destinados al consumo a escala global se originaron a partir de la influencia capitalista en sus desarrollos sociales y políticos y, además, ayudaron en la dinámica de estos mismos procesos, yendo más allá del nicho literario. Así, se buscó mapear, entre los jóvenes participantes, hábitos literarios y culturales relacionados con el mercado y el entretenimiento. Para ello se utilizó el soporte teórico y metodológico, junto con la investigación de campo, con el fin de estudiar la relación que los jóvenes integrantes de la investigación establecen con la literatura destinada al consumo a gran escala y mediada por la industria cultural. Se verificó mediante un cuestionario autoadministrado, la situación socioeconómica de los estudiantes investigados, los patrones de consumo y, de qué manera, la literatura de amplio alcance mediático ha influido en el comportamiento de los jóvenes en sus decisiones de compra y entretenimiento.
\end{abstract}

Palabras clave: Literatura. Joven. Consumo. Mercado. Entretenimiento.

\section{Comportamentos de consumo derivados da literatura: considerações iniciais}

As ações culturais, leituras e as mais variadas relações e interações humanas, cada vez com mais intensidade, estão sendo modificadas, de forma a se adaptarem aos dias atuais e aos fenômenos culturais, sociais e políticos que hoje se desenvolvem. No ensaio "A obra de arte na era de sua reprodutibilidade técnica", publicado em 1936, Walter Benjamin (1994) expressou que a obra de arte de um modo geral, e a literatura em particular, podem ser concebidas como uma mercadoria que atinge ao público mediante a possibilidade de ser adquirida por muitos, a fim de ser consumida conforme a demanda do cliente. Benjamin, que diferencia a obra de arte da mercadoria por meio do conceito de aura, que "é uma figura singular, composta de elementos espaciais e temporais: a aparição única de uma coisa distante, por mais perto que ela esteja", esclarece que, na reprodução de um objeto com fins mercadológicos "o que se atrofia na era da reprodutibilidade técnica da obra de arte é sua aura" (BENJAMIN, 1994, p. 170). Nesse processo de declínio da aura, Benjamin (1994) evidencia que a técnica da reprodução separa do domínio da tradição o objeto reproduzido, substituindo, dessa forma, a exclusividade única da obra por uma existência serial. A técnica industrial, que possibilita a multiplicidade dos produtos, permite que tudo o que pode ser reproduzidos alcance o espectador, ou consumidor (NOLASCO, 2007). 
Nessa perspectiva, conforme Bourdieu (2009), o mercado de bens culturais, a indústria do entretenimento, entre outros elementos que influenciam a interação com o mundo e a arte, estão transformando a percepção a respeito de conceitos teóricos já estabelecidos, em relação à própria ideia de arte e cultura. Destaca-se, ainda, a influência irreversível das novas tecnologias de comunicação e informação, as quais possibilitam a troca imediata de conteúdo e, ainda, permitem um contato amplo com diversos espaços virtuais e diferentes comunidades que, atualmente, podem ser acessadas em tempo real, independentemente da distância em que estão localizadas, tal como questiona Canclini (2016, p. 89):

Como pode ser desenvolvida uma perspectiva que sintonize com as práticas culturais? Uma via é registrar como desmaterializam as artes e a literatura na era de sua reprodutibilidade tecnológica. As relações da escrita e da literatura com o audiovisual e o digital conduzem a um novo regime simbólico. Dissolve-se a consistência da arte e da literatura, como algo diferente do nada, que resiste a ele, nestes tempos de fluxo digital generalizado de imagens e escritas?

Dessa forma, a reorganização e recriação de espaços físicos, conceituais e virtuais, além de novas definições de interatividade e de comunidades locais e globais, dentre outros fenômenos em atuação pelo mundo, apresentam uma nova posição a respeito da cultura, incluindo-se, nesse âmbito, a literatura. Um dos mais emblemáticos exemplos da ação desses fatores na literatura é o fenômeno da publicação de livros destinados ao consumo em grande escala, como as sagas literárias, o qual foi estimulado pela globalização dos mercados e novos padrões culturais. Esse processo se apresenta, hoje, como devedor e, ao mesmo tempo, credor da globalização e do capitalismo na literatura, principalmente quando se destaca o mercado editorial e a indústria do entretenimento.

Os grandes fenômenos literários destinados ao consumo em escala global originaram-se da influência capitalista em seus desdobramentos sociais e políticos e, em igual perspectiva, auxiliam na dinâmica desses mesmos processos, ultrapassando o nicho literário. À proporção que estabelece diálogo com as diferentes mídias essa forma literária se torna capaz de criar e manter redes mundiais de conexão interativas, as quais, atualmente, não são mais apenas imaginadas ou idealizadas, mas compartilhadas por suas comunidades de forma virtual. O fato de transpor as mais diversas fronteiras, tanto de natureza física quanto ideológica, mostra o fator globalizante das publicações direcionadas ao consumo em grande escala em sua vertente contemporânea. A capacidade de integralização dessas obras é, certamente, a sua principal característica, a qual é representada pela criação, ou ocupação do espaço comum, compartilhado pelos mais diversos sujeitos e suas comunidades interpretativas de alcance global. Nesse contexto, Canclini (2008, p. 22) define os conceitos de "leitor", "espectador" e "internauta":

O conceito de leitor foi trabalhado no marco de uma teoria dos campos, quer de forma restrita como leitor de literatura (Iser, Jauss), quer no sentido mais sociológico, como destinatário do sistema editorial (Chartier, Eco). Essa delimitação fica ainda mais estrita quando o leitor é incorporado como personagem em obras tão diversas quanto a de Macedonio Fernández, que destaca o leitor artista ('o que não procura uma solução'), ou no romance de Italo Calvino, que opõe a leitura ao mundo televisivo.

A noção de espectador, embora mais difusa, foi definida em relação a campos específicos ao falar do espectador de cinema, de televisão ou de recitais de música. Cada um, formado numa lógica diferente, mobiliza disposições diversas quando vai assistir um filme, está numa sala de concertos ou liga a televisão.

Em compensação, se falamos de internauta, fazemos alusão a um agente multimídia que lê, ouve e combina materiais diversos, procedentes da leitura e dos espetáculos. Essa integração de ações e linguagens redefiniu o lugar onde se aprendiam as principais habilidades - a escola - e a autonomia do campo educacional. 
O leitor, incialmente preso às páginas dos livros, entra em um universo antes apenas apreendido pelas palavras no papel ou, até mesmo, presentes na tela do cinema e do computador. Porém, agora, mesmo que de forma virtual, o leitor passa a ser parte do universo da série por meio de uma funcionalidade e de uma interatividade inatingíveis no livro como suporte, tal como destaca Canclini (2008, p. 33, grifo do autor):

As fusões multimídia e as concentrações de empresas na produção de cultura correspondem, no consumo cultural, à integração de rádio, televisão, música, notícias, livros, revistas e Internet. Devido à convergência digital desses meios, são reorganizados os modos de acesso aos bens culturais e às formas de comunicação. Parece mais fácil aceitar o processo socioeconômico das fusões do que reconsiderar o que vinha sendo sustentado nos estudos sobre educação e leitura, nas políticas educacionais, culturais e de comunicação.

Essa disseminação de um bem cultural por meio das mais diversas mídias, do cinema aos jornais e sites de notícia e redes sociais, faz com que esse produto do mercado editorial e da indústria cultural, seja relevante nos multimeios e, ainda, atraía uma multidão de leitores. É justamente no fato de transpor as barreiras das diferentes mídias e na capacidade de habitá-las de forma harmoniosa que os textos ficcionais produzidos e destinados ao consumo em escala global se apresentam, além de um fenômeno literário, como um processo cultural de amplo alcance.

No capítulo de abertura do livro Mercado editorial brasileiro, 1960-1990, o qual se intitula "Sobre a noção de best-seller", Reimão (1996, p. 23) aponta duas áreas de significação deste termo, de modo que a primeira seria quantitativa e comparativa, mostrando "os livros mais vendidos de um período em um local". A segunda seria de natureza qualitativa, apresentando uma modalidade de texto, que também seria denominado como "paraliteratura, literatura trivial, subliteratura, literatura de entretenimento, de massa ou de mercado" (REIMÃO, 1996, p. 23). Reimão (1996, p. 23) destaca:

Há um consenso de que essa literatura, descendente do romance-folhetim, expandiu-se a partir de meados do século XIX e especialmente no século XX, e de que esses textos devem ser inseridos na lista dos primeiros produtos da indústria cultural, a qual, por sua vez, é veiculada à fase monopolista do capitalismo e à sociedade de consumo. À parte esse consenso, há várias formas de caracterizar a literatura de massa.

Sodré (1985), em Best-seller: a literatura de mercado, mostra quatro tipos de característica desta literatura: a presença de um herói super-homem, a atualidade informativo-jornalística, as oposições míticas e a preservação da retórica culta. Ainda Reimão (1996, p. 26), discorre sobre outras classificações, como as de Todorov e Ducrot (1976), "que caracterizam a literatura de massa como aquela em que a obra individual se conforma inteiramente ao gênero e ao tipo". A divisão entre best-sellers e os livros considerados como mais cultos gera uma discussão da função social e intelectual da obra, além de apresentar perfis de leitores diferenciados. A leitura chamada trivial repetiria e afirmaria o mundo da maneira como ele é, enquanto a considerada alta literatura traria uma mudança no interior do seu leitor, apresentando uma nova percepção de mundo. E, além disso, a sua leitura não seria facilitada (REIMÃO, 1996).

A partir da observação comportamental dos jovens em relação aos seus padrões de consumo cultural, de modo geral, e, mais especificamente, dos sujeitos ao qual esse estudo foi direcionado, a presente pesquisa objetivou investigar como jovens de uma comunidade do interior do Rio Grande do Sul, distante dos grandes centros comerciais, interagem com a literatura estrangeira, produzida para o mercado global, bem como a mesma interfere em seus padrões de consumo. 
A pesquisa foi desenvolvida em duas modalidades, consistindo, primeiramente, em um levantamento bibliográfico e documental, seguido de um estudo exploratório ${ }^{1}$. Durante a primeira etapa ocorreu uma investigação envolvendo o posicionamento dos jovens sobre temas como teoria da literatura, estética da recepção, as relações que permeiam textos literários que se caracterizam como grandes fenômenos globais e os comportamentos de consumo, que são desencadeados a partir das respectivas produções literárias. Investigou-se, nessa fase, quais são as relações que se estabelecem entre mercado literário, comportamento consumidor e projeções identitárias forjadas a partir de hábitos de consumo desencadeados pela literatura.

A segunda etapa consistiu na aplicação de um questionário, que foi respondido por alunos do Instituto Federal Farroupilha - Campus São Borja. O respectivo instrumento foi construído por perguntas abertas e fechadas, com a função de verificar o padrão socioeconômico, hábitos de consumo e influência de textos literários de grande impacto mercadológico sobre as escolhas de compra dos jovens participantes. A primeira versão do questionário passou por um procedimento de testagem. Diante dos resultados obtidos, nessa fase inicial, foram feitas as adequações que se julgarem pertinentes, a fim de se preparar a versão definitiva do respectivo questionário, que foi aplicado de maneira subsequente. Após esse procedimento os dados obtidos foram apurados e sistematizados estatisticamente, em forma de gráficos e tabelas para, em seguida, serem analisados e interpretados.

\section{Perfil socioeconômico dos jovens participantes}

A primeira parte do questionário aplicado aos alunos foi constituída de questões voltadas à caracterização do perfil socioeconômico dos jovens participantes da pesquisa. Em um estudo desta natureza, o qual objetiva compreender os mecanismos que impulsionam o comportamento consumidor de produtos culturais, criados a partir de textos literários, é importante que sejam delineadas as condições materiais de acesso à aquisição destes bens, tanto em sua forma física quanto virtual. Considerando o posicionamento de Bourdieu (1983), segundo o qual a sociedade organiza a distribuição dos bens materiais e simbólicos ao mesmo tempo e com procedimentos semelhantes aos que utiliza para estruturar, nos grupos e indivíduos, a relação subjetiva com eles, quando os sujeitos selecionam ou simulam o teatro das preferências, estão, a rigor, representando os papéis que o sistema social lhes fixou. Nessa perspectiva, os dados subsequentes transcrevem as respostas fornecidas pelos alunos concernentes à idade, renda familiar, habitação, acesso à internet, canais de televisão e equipamentos tecnológicos.

Responderam ao questionário da pesquisa 107 alunos, dos quais $64 \%$ encontram-se na faixa etária correspondente entre 16 a 18 anos; 35\% entre 19 a 21 anos; e apenas $1 \%$ declarou possuir mais de 21 anos.

A respeito da renda familiar, em salários-mínimos, $11 \%$ declararam ser inferior a um salário; $61 \%$ afirmaram estar entre 1 a 3 salários; $20 \%$ entre 4 a 6 salários; e $8 \%$ acima de 10 salários-mínimos.

Sobre a localização da residência familiar, 53,6\% dos participantes informaram morar em bairros próximos ao Centro; $23,8 \%$ em área urbana central; 20,2\% em área urbana periférica; e $2,4 \%$ em comunidade rural. No que diz respeito às condições da residência onde os sujeitos investigados habitam, $76,2 \%$ responderam que a família vive em casa própria, já quitada; 7,1\%, têm casa própria, mas está sendo financiada; $14,3 \%$ vivem em casa alugada; e 2,4\% moram em residência emprestada ou cedida por familiares, amigos ou patrões.

1 A pesquisa, financiada pelo Programa de Apoio à Iniciação Científica no Ensino Técnico (modalidade integrado) - PAIC-ET1, foi desenvolvida no Instituto Federal Farroupilha - Campus São Borja, entre agosto de 2018 a março de 2020. 
Em referência aos equipamentos tecnológicos que os participantes possuem em sua residência, conforme demonstra o Gráfico 1, verificou-se que $94 \%$ têm smartphone; 78,6\% têm laptop; $61,9 \%$ possuem mais de um aparelho de televisão; 35,7\% têm tablet; e 28,7\% possuem outros tipos de equipamentos.

Gráfico 1 - Tipos de equipamentos tecnológicos que os participantes do questionário têm em casa

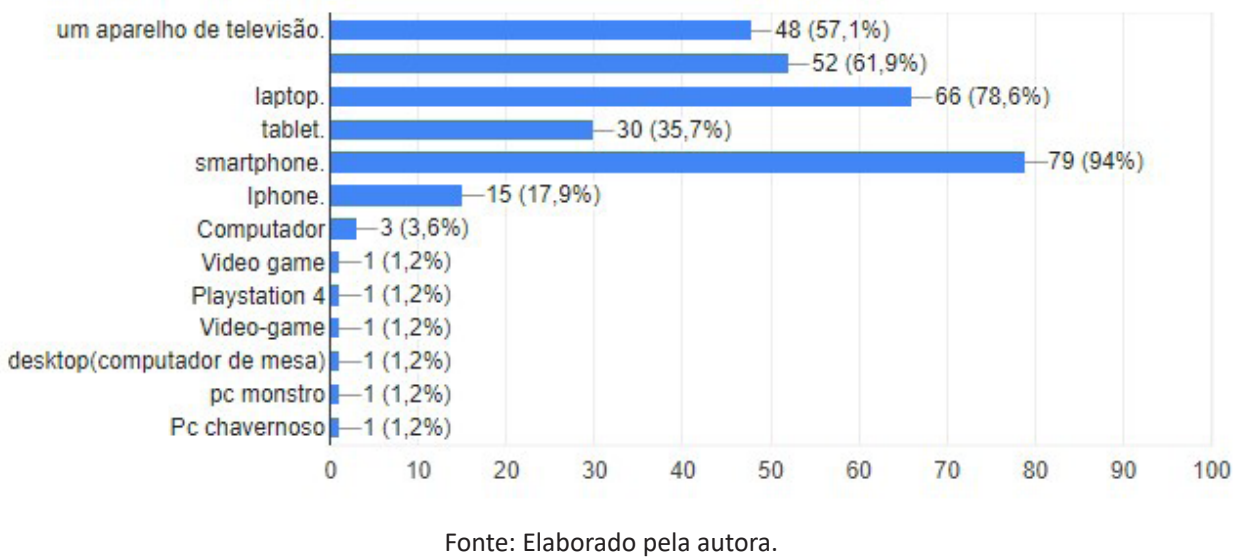

Quando investigados a respeito do acesso à internet em casa, verificou-se que 95,2\% dos alunos participantes têm esse meio em sua residência, enquanto $4,7 \%$ não usufruem deste recurso. Sobre acesso à televisão por assinatura verificou-se que $60,2 \%$ dos sujeitos investigados dispõem desta alternativa de entretenimento; 34,9\% fazem uso de streamings (Netflix, Amazon Prime, etc.); e $4,9 \%$ não têm acesso a estes canais.

De forma panorâmica constatou-se que a maioria dos sujeitos investigados $(77,4 \%)$ vivem em área central ou próxima ao centro da cidade; $83,3 \%$ declararam que a família reside em casa própria; $95,2 \%$ têm acesso à internet; e $94 \%$ possuem smartphone, o que sugere que a maioria dos alunos que frequentam o Ensino Médio Técnico Integrado do Instituto Federal Farroupilha - Campus São Borja, têm boa qualidade de vida e acesso à tecnologia, o que viabiliza o consumo de bens produzidos pela indústria cultural. Esse aspecto, ainda em consonância com Bourdieu (1983), evidencia que, se existe uma homologia entre a ordem social e as práticas dos sujeitos, incluindo neste ponto o consumo cultural, a mesma não deriva do poder educativo, publicitário ou político, mas porque essas ações estão inseridas em sistemas de hábitos, constituídos, em sua grande maioria, desde a infância.

\section{Apresentação e análise dos resultados obtidos}

A segunda parte do questionário buscou identificar o motivo pelo qual textos literários, que se expressam como grandes fenômenos de vendas e, por consequência, passam a ser adaptados para o cinema, séries televisivas, jogos computacionais, além de receberem inúmeros produtos comerciais licenciados, influenciam o comportamento consumidor dos jovens participantes da pesquisa. Dessa maneira, objetivou-se verificar quais são os mecanismos que acionam, nos sujeitos investigados, os hábitos de leitura de obras de grande impacto comercial e a forma como se delineia o comportamento consumista dos jovens, impulsionados pela literatura desta natureza. Pretendeu-se entender as razões que conciliam a imersão no texto literário ao mercado, permeadas por elementos como cultura e entretenimento na definição dos seus hábitos de consumo. 


\section{Gráfico 2 - Hábitos de leitura}

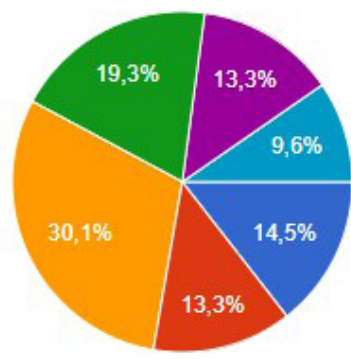

Não constumo ler.

Leio só por exigência de disciplinas escolares.

Leio algum livro esporadicamente.

Leio regularmente.

Tenho bons hábitos de leitura.

Leio muito.

Fonte: Elaborado pela autora

\section{Gráfico 3 - Média de livros lidos anualmente pelos alunos investigados}

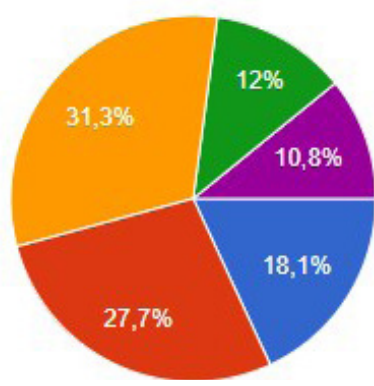

Menos de um.

Entre um e três livros.

Entre quatro a seis livros.

Entre sete a dez livros.

Acima de dez livros.

Fonte: Elaborado pela autora

Quando questionados sobre os hábitos de leitura, conforme o Gráfico 2, verificou-se que 9,6\% dos participantes afirmaram ler muito; $13,3 \%$ disseram ter bons hábitos; 19,3\% responderam ler regularmente; $30,1 \%$ leem algum livro esporadicamente; $13,3 \%$ destacaram ler por exigência de disciplinas escolares; 14,4\% afirmaram que não costumam ler. Em relação à média de livros lidos anualmente, verificou-se que $18,1 \%$ dos participantes afirmaram ler menos de um livro por ano; $27,7 \%$ entre um e três livros; $31,3 \%$ entre quatro a seis livros; $12 \%$ entre sete a dez livros; e 10,8\% acima de dez livros anualmente. Os respectivos percentuais indicam que há uma coerência entre o índice de alunos que responderam ler muito ou ter bons hábitos de leitura $(22,9 \%)$ com a média de livros lida atualmente por este público mais costumaz, que leem mais de dez livros a cada ano ou entre sete a dez obras literárias (22,8\%). O maior índice é de leitores medianos $(49,4 \%)$, mas ainda assim é alto o número de alunos que não leem ou o fazem esporadicamente (27,7\%).

Segundo dados do Instituto Pró-Livro (2019), que coordenou a pesquisa Retratos da Leitura no Brasil, atualmente em sua quinta edição, a média de livros lidos no país, por habitante, é de 2,55 ao ano, considerando diversas variáveis como idade, gênero, classe social, nível de escolaridade e região. Tendo em vista que os alunos participantes da pesquisa, de modo geral, têm boas condições socioeconômicas e, ainda, dispõem, no Instituto Federal Farroupilha - Campus São Borja, de uma biblioteca com acervo significativo e excelente infraestrutura, é considerado elevado o percentual de alunos que afirmaram não ler ou pouco praticar a leitura. Ainda que, neste estudo, não objetivamos delinear as razões que apontam para este comportamento, compreende-se que o hábito leitor, além de refletir um padrão cultural que, muitas vezes, não possuí consonância com o nível socioeconômico, está gradativamente perdendo espaço para equipamentos maior interatividade e poder de conexão, como os dispositivos móveis e as redes sociais. 
Figura 1 - Leitores de Harry Potter

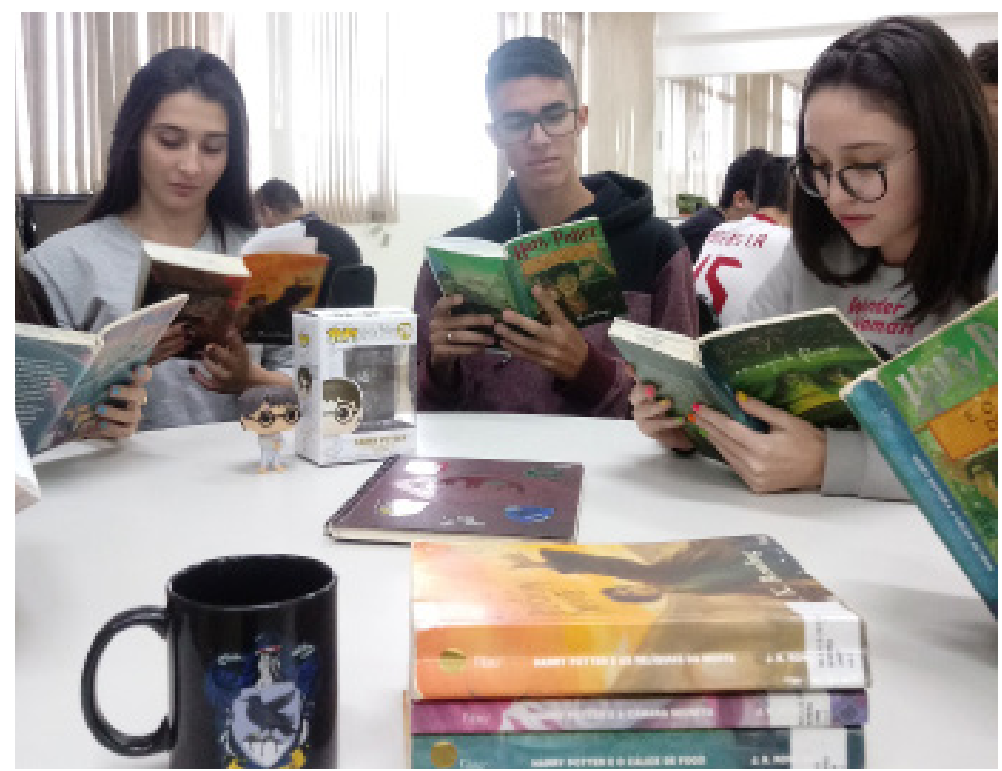

Fonte: Acervo da autora.

Gráfico 4 - Percentual de leitores dos livros da saga Harry Potter

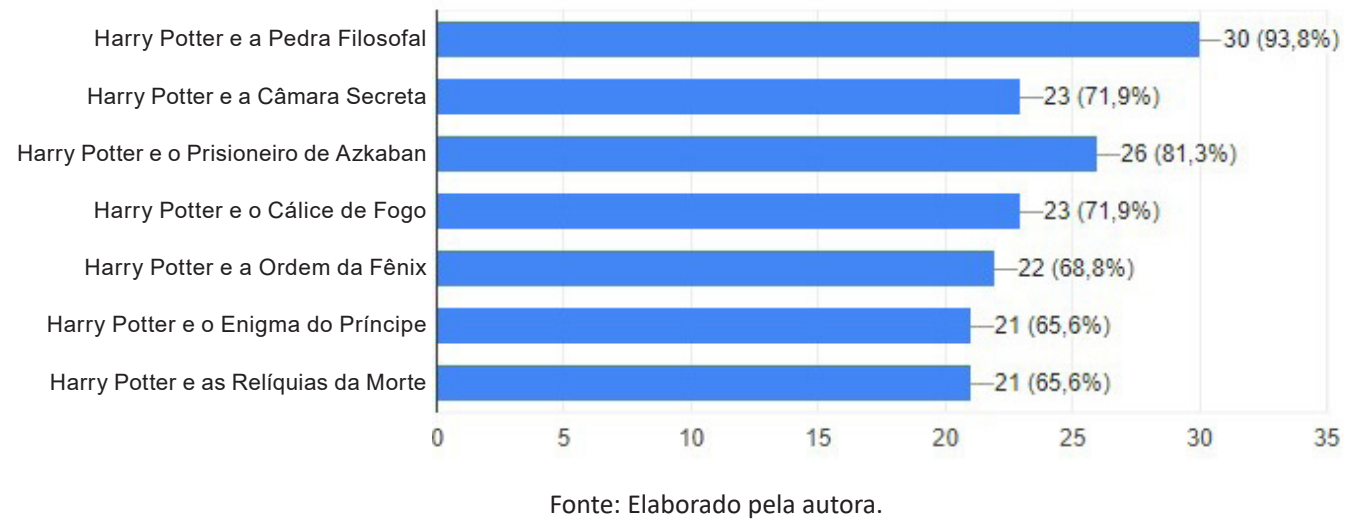

Ao se questionar a respeito de quais livros, considerados fenômenos editoriais ${ }^{2}$, foram lidos pelos participantes da pesquisa, constatou-se que, sobre as publicações referentes a saga Harry Potter, de autoria da escritora britânica J. K. Rowling, cujos lançamentos ocorreram entre 1997 a 2007, o percentual de leitura apresentou-se da seguinte forma: 93,8\% dos alunos investigados leram Harry Potter e a Pedra Filosofal (1997); Harry Potter e a Câmara Secreta (1998) foi lido por 71,9\% dos participantes da pesquisa; Harry Potter e o Prisioneiro de Azkaban (1999) obteve um índice de leitura de 81,3\%; Harry Potter e o Cálice de Fogo (2000), apresentou-se lido por 71,9\% dos alunos; Harry Potter e a Ordem da Fênix (2003) chegou a 68,8\% dos alunos investigados; Harry Potter e o Enigma do Príncipe (2005), por 65,6\% dos sujeitos pesquisados; e Harry Potter e as Relíquias da Morte (2007), atingiu 65,6\% dos participantes.

\footnotetext{
2 Além das principais sagas analisadas neste estudo, entre os livros mencionados pelos entrevistados apareceram nomes como a saga A Seleção, de autoria da norte-americana Kiera Cass, publicada entre 2012 a 2016; a saga Percy Jackson, publicada entre 2005 a 2009, pelo escritor norte-americano Rick Riordan; os livros da saga do Tigre, da autora americana Colleen Houck, publicados entre 2011 a 2018; Jogos vorazes (2008), de autoria da norte-americana Suzzanne Collins; A culpa é das estrelas (2008), do estadunidense John Green; Sherlock Holmes, originalmente publicado em 1887, pelo britânico Sir Arthur Conan Doyle; os livros do autor norte-americano Stephen King (1947); O Mágico de Oz (1900), do autor norte-americano L. Frank Baum; O Pequeno Príncipe (1943), do francês Antoine de Saint-Exupéry; O menino do pijama listrado (2006), do autor irlandês John Boyne, além de outras referências que, proporcionalmente, atingem o percentual de $3 \%$.
} 
Harry Potter foi uma obra que recebeu muitas categorizações no decorrer dos dez anos que separaram o lançamento do primeiro livro, A Pedra Filosofal (1997), do último livro, As Relíquias da Morte (2007). Inicialmente, tais rótulos apresentam-se em uma relação de polaridade, uma vez que abarcam desde a formulação sobre o público a quem os livros se destinam, crianças e adolescentes, até os números elevados que geralmente acompanham o nome "Harry Potter", como recordes de vendas de livros e de bilheteria, em suas adaptações para o cinema, além de produtos licenciados. Embora o questionamento acerca do valor literário da saga seja objeto constante de críticas acadêmicas, tais como explicitou Harold Bloom (2000), em seu famoso artigo Can 35 Million Book Buyers Be Wrong? Yes., o autor compara Harry Potter aos grandes ícones de cultura pop que se mostraram presentes na transição do século XX para XXI. Segundo Bloom (2000, p. 50, tradução nossa):

Pode-se razoavelmente duvidar que Harry Potter e a Pedra Filosofal vai se provar um clássico na literatura infantil, mas Rowling, apesar da fraqueza estética de seu trabalho, é, ao menos, um índice milenar para a nossa cultura popular. Uma imensa plateia atribui-lhe importância semelhante àquela atribuída a estrelas do rock, ídolos de cinema, âncoras de TV e políticos bem sucedidos. O estilo de sua prosa, carregado de clichês, não faz exigências aos seus leitores.

Conforme indicam os índices de leitura levantados na pesquisa, os livros que compõem a saga Harry Potter foram os mais lidos pelos alunos, o que comprova que, embora se questione o seu valor como obra literária, é inegável o seu alcance e sucesso junto ao público leitor. Em análise relativa ao fenômeno, Nakagome e Francisco (2014, p. 438) apontam:

[...] é ainda mais provável que os leitores de Harry Potter, tantos e tão variados ao redor do mundo, tenham visto algo que vai muito além de rótulos editoriais. Apenas isso justifica que a série tenha sido acompanhada ao longo de tantos anos e tantas páginas. Talvez eles tenham chegado à obra por causa de algum de seus rótulos, mas mantiveram seu interesse por ela pelo que estava além dessas tentativas sempre falhas de ordenação e delimitação.

Figura 2 - Leitores de J.R.R Tolkien

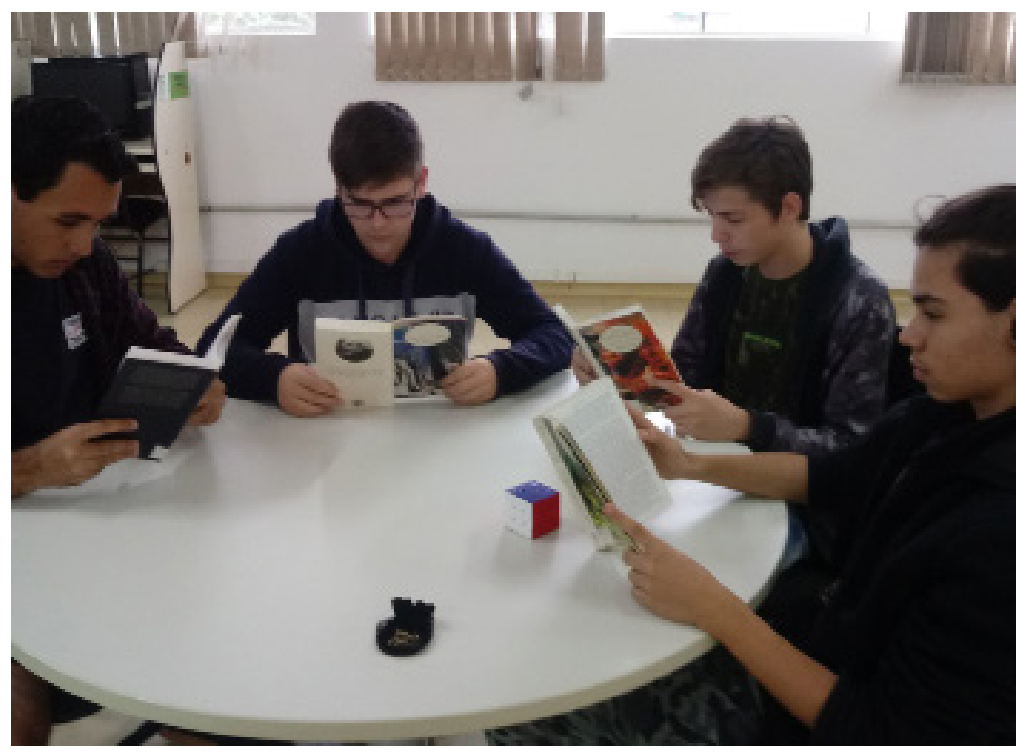

Fonte: Acervo da autora. 


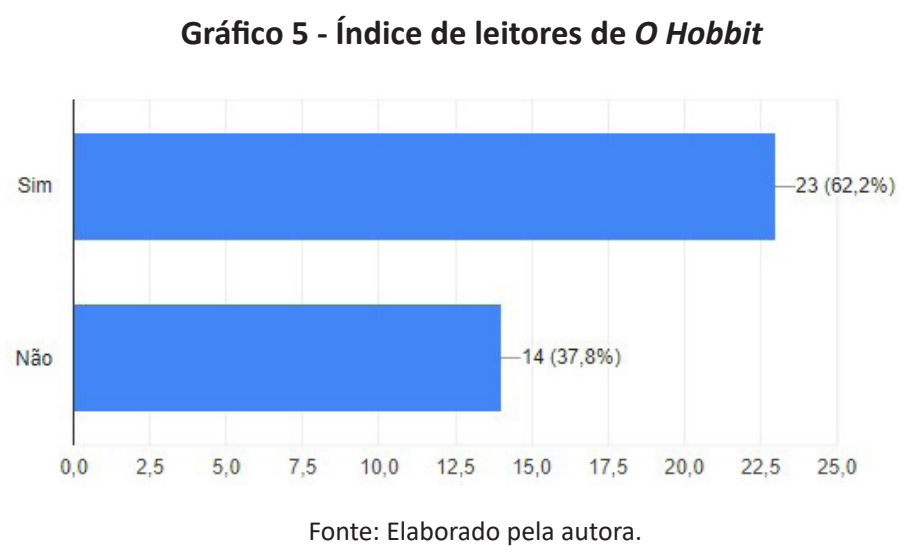

Figura 3 - Leitores de $O$ Senhor dos Anéis

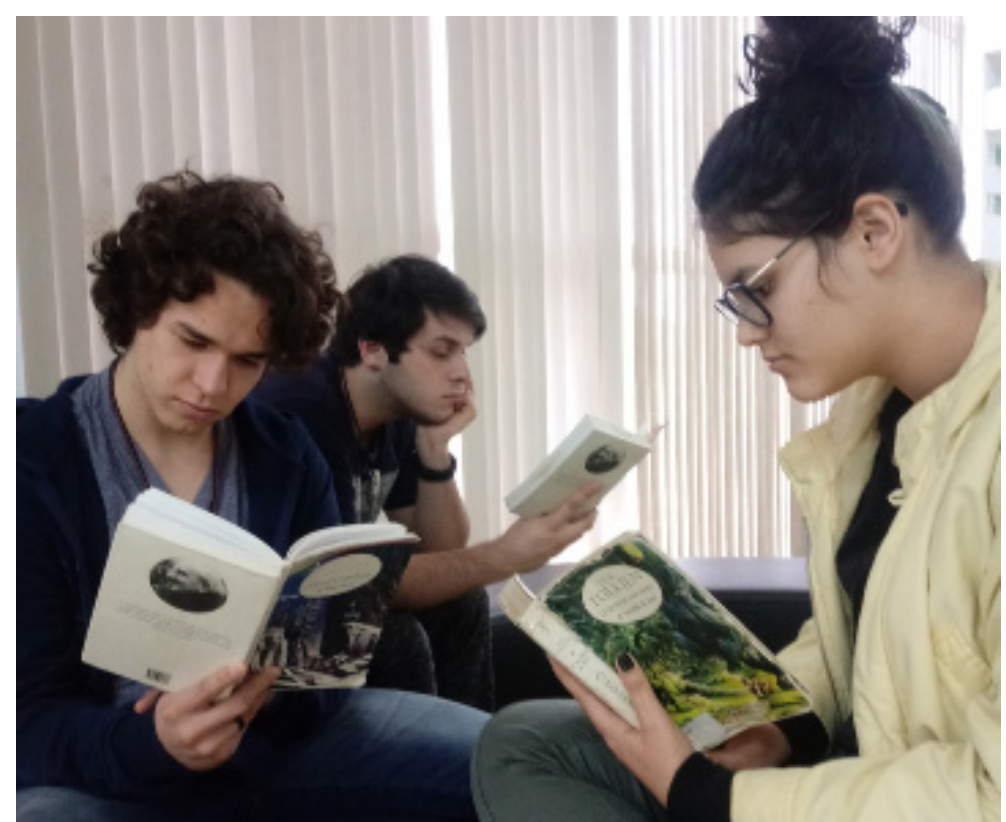

Fonte: Acervo da autora.

Gráfico 6 - Índice de leitores de $O$ Senhor dos Anéis

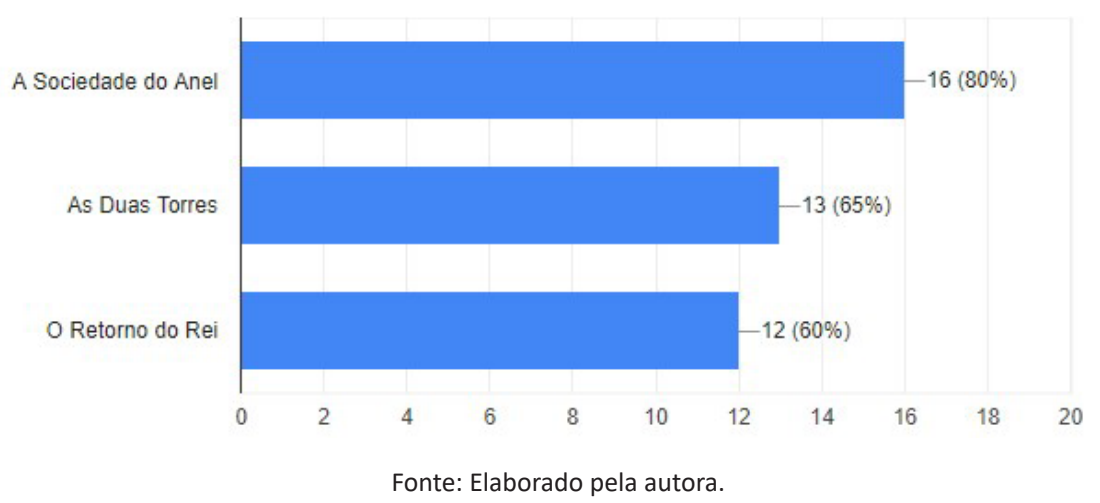

A respeito da trilogia $O$ Senhor dos Anéis, do autor britânico J. R. R. Tolkien, publicada entre 1954 a 1955, verificou-se que 80\% dos alunos leram A Sociedade do Anel (1954); 65\% fizeram a leitura de As Duas Torres (1954); e 12\% leram O Retorno do Rei (1955). De acordo com as respostas fornecidas ao questionário, 62,2\% dos alunos leram O Hobbit (1937), também de J.R.R. Tolkien, que 
constituí uma espécie de preâmbulo de O Senhor dos Anéis. Apesar do grande sucesso editorial das obras de J. R. R. Tolkien, diferente da maioria das sagas que foram escritas com esse propósito, o autor não construiu a sua ficção com o objetivo de conquistar o público leitor e, consequentemente, o consumo massivo. J. R. R. Tolkien, que foi professor catedrático na Universidade de Oxford, possui uma vasta produção mitológica e literária, baseada em anos de pesquisa em filologia, mitologia nórdica e germânica, estudos medievais, entre outros. Todavia, a maior parte de sua produção configurou-se como um painel para as suas duas maiores obras publicadas em vida, $O$ Hobbit e $O$ Senhor dos Anéis. Considera-se, além disso, que seus estudos serviam também para deleite pessoal, uma vez que suas pesquisas não foram feitas com o objetivo de serem publicadas. O Professor, como era conhecido pelo ofício que exercia em Oxford, escreveu $O$ Hobbit, inicialmente, para contar histórias aos seus filhos pequenos, mas a narrativa acabou chegando ao conhecimento de Susan Dagnall, membro da editora George Allen \& Unwin, que o convenceu a enviar a história para tentar publicá-la. Com o grande sucesso da saga, a editora solicitou uma nova obra que pudesse dar continuidade ao livro lançado (SEMMELMANN, 2017).

A respeito da expressão "literatura de massa", convém, aqui, destacar algumas considerações de Christopher Tolkien, falecido em 2020 e terceiro filho do escritor que, até então, detinha os direitos autoriais das obras do pai. Em entrevista ao jornal Le Monde, na reportagem Tolkien, o anel da discórdia, de 2012, afirma não ter aprovado os filmes dirigidos por Peter Jackson: "Eles arrancaram as vísceras do livro, tornando-o um filme de ação para jovens entre 15 a 25 anos", diz Christopher. Para o filho do autor, J. R. R. Tolkien foi devorado pela sua própria popularidade e absorvido. E ele prossegue em sua entrevista ao Le Monde: "A comercialização reduziu o impacto estético e filosófico da obra a nada. Há apenas uma solução para mim. Virar o meu rosto para outro lado" (RÉROLLE, 2012).

O posicionamento de Christopher Tolkien, bem como de seu pai, contrários a representação imagética da fantasia, contradizem o senso comum acerca do best-seller, ainda que O Senhor dos Anéis tenha excelentes razões para ser considerado uma literatura do gênero. Conforme a reportagem do Le Monde, em 2012, só a saga do Anel teria vendido cerca de 150 milhões de livros e sido traduzida para 60 idiomas. Com as adaptações para o cinema, de 2001 a 2003, foram vendidas 25 milhões de cópias impressas de $O$ Senhor dos Anéis, fazendo com que as vendas do livro, apenas no Reino Unido, subissem $1000 \%$ após o lançamento do primeiro filme da trilogia.

Figura 4 - Leitora de As Crônicas de Nárnia

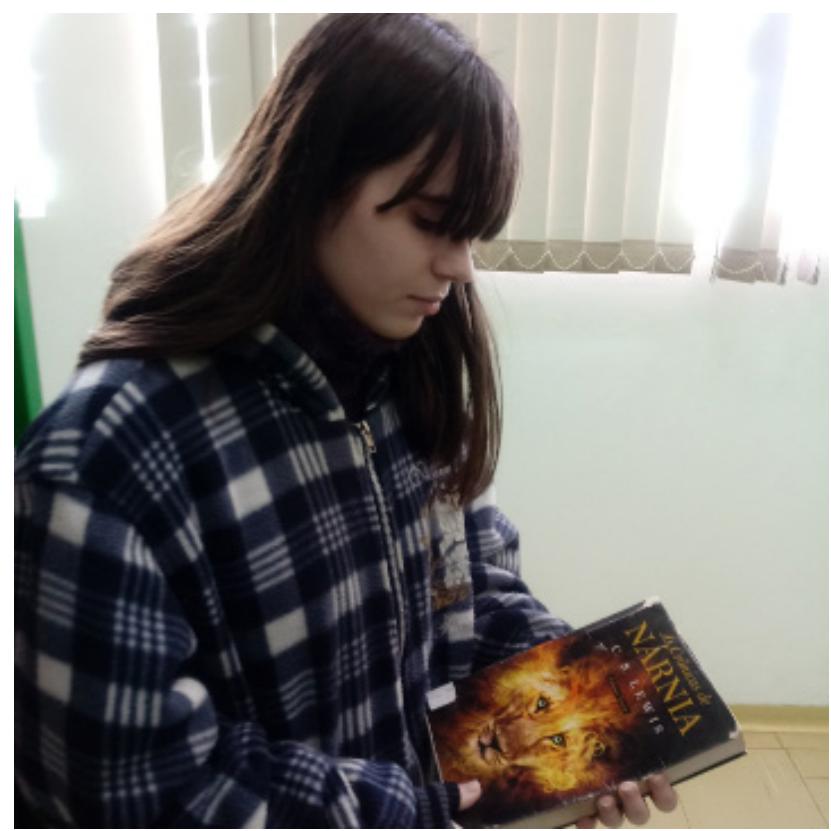

Fonte: Acervo da autora. 
Gráfico 7 - Percentual leitores dos livros da saga As Crônicas de Nárnia

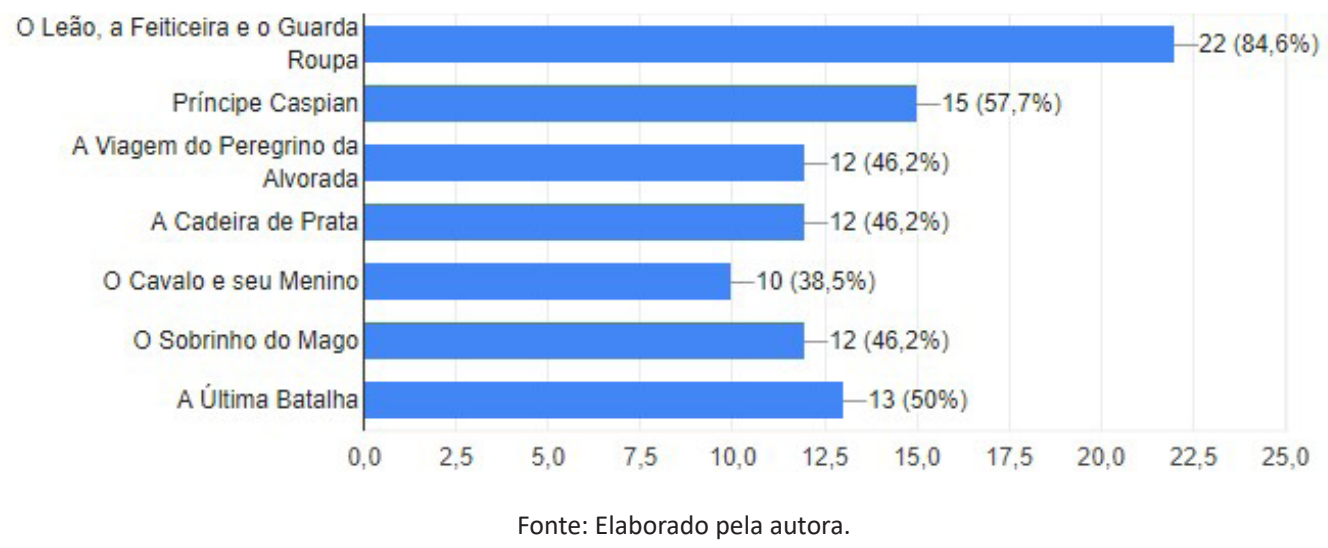

Sobre a saga As Crônicas de Nárnia, do autor irlandês C. S. Lewis, publicadas entre 1950 a 1956, os índices de leitura obtiveram os seguintes percentuais: $84,6 \%$ dos alunos afirmaram ter lido O Leão, a Feiticeira e o Guarda-Roupa (1950); 57,7\% leram Príncipe Caspian (1951); 46,2\% fizeram a leitura de A Viagem do Peregrino da Alvorada (1952); A Cadeira de Prata (1953) foi lida por 46,2\%; 38,5\% dos participantes leram O Cavalo e seu Menino (1954); 46,2\% realizaram a leitura de O Sobrinho do Mago (1955); e 50\% leram A Última Batalha (1956).

Clives Staples Lewis (1898-1963) não apenas escreveu um dos maiores best-sellers do mundo como também produziu livros de diferentes gêneros: literatura infantil e juvenil, ficção científica, crítica literária, apologética, autobiografia, entres outros. Lewis foi professor de literatura medieval e renascentista em Oxford e em Cambridge, e sua produção sobre a crítica literária e o ensino da literatura reflete a erudição de seu autor. Era conhecedor do inglês nativo e de grego e latim clássicos, o que lhe permitia trabalhar com as fontes primárias daquilo que ensinava (LOPES, 2017).

O lançamento da adaptação fílmica em 2005 trouxe um impacto na produção do livro, o que já havia acontecido com a obra O Senhor dos Anéis. A obra ficcional de Lewis, além de prestigiada na Europa e nos Estados Unidos, ocupa o sétimo lugar na literatura mundial e já foi traduzida para o Oriente. Desde a segunda metade do século XX, as obras de Lewis já apresentavam destaque nos EUA e na Europa, em virtude da publicação dos sete livros da série (entre 1950-1956) e das palestras do autor proferidas pela $\mathrm{BBC}$ de Londres à população que buscava a reestruturação da vida no mundo após a segunda Guerra Mundial. A obra literária tornou-se mais conhecida, no Brasil, na ocasião do lançamento do filme As Crônicas de Nárnia: O Leão, a Feiticeira e o Guarda-Roupa, em 2005 (LOPES, 2017).

Figura 5 - Leitores de As Crônicas de Gelo e Fogo

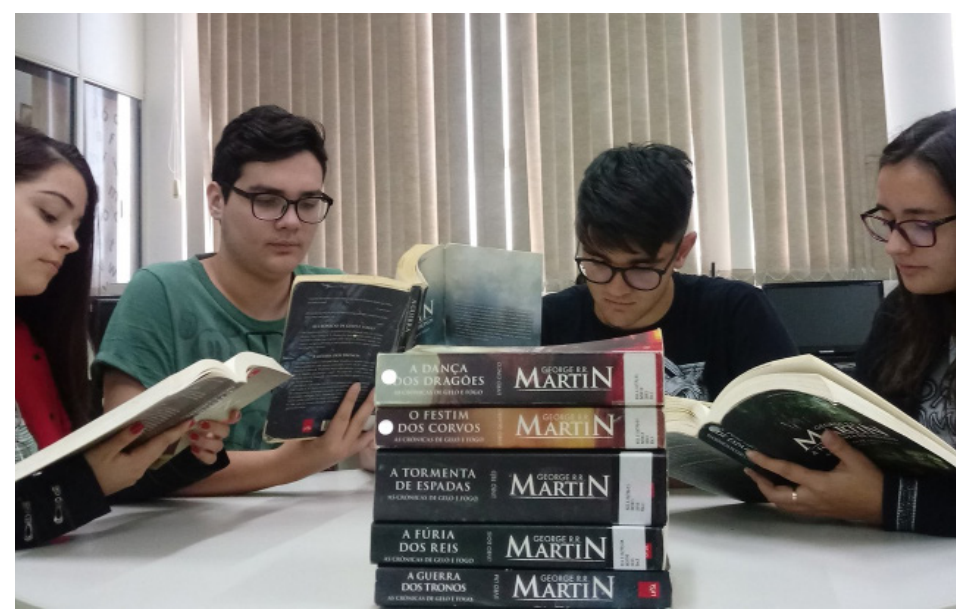

Fonte: Acervo da autora. 
Gráfico 8 - Percentual leitores dos livros da saga As Crônicas de Gelo e Fogo

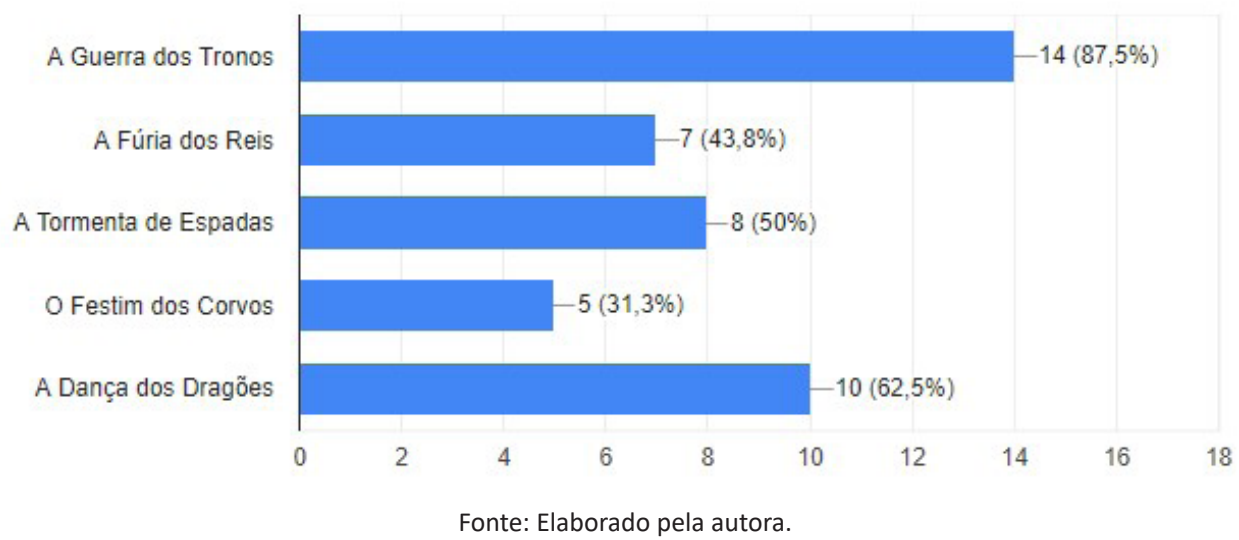

No que diz respeito aos livros da saga As Crônicas de Gelo e Fogo, do norte-americano George R. R. Martin, publicadas entre 1996 a 2011, verificou-se que 87,5\% dos alunos já leram A Guerra dos Tronos (1996); 43,8\% realizaram a leitura de A Fúria dos Reis (1988); 50\% leram A Tormenta de Espadas (2000); O Festim dos Corvos (2005) foi lido por 31,3\%; e 62,5\% leram A Dança dos Dragões (2011).

Conforme Burlamaque e Barth (2016), a série As Crônicas de Gelo e Fogo, escritas pelo escritor norte-americano George R. R. Martin, iniciaram no formato livro e se expandiram para outras plataformas e mídias, alcançando um grande sucesso comercial. O primeiro volume da série, Guerra dos Tronos (Game of Thrones), foi publicado nos Estados Unidos em $1996 \mathrm{e}$ traduzido para mais de vinte idiomas. Ao Brasil, chegou apenas em 2010, publicado pela editora Leya. O autor prevê que a série literária terá sete volumes; destes, cinco já foram publicados. Além dos livros, o universo de Martin recebeu adaptações e ampliações em séries de televisão, quadrinhos, vídeo games, entre outros.

A mais célebre das adaptações é a série Game of Thrones, criada por David Bernioff e Daniel Brett Weiss em 2011, e produzida pelo canal HBO, a qual foi amplamente assistida pelos alunos participantes da pesquisa. A série recebeu a supervisão do próprio George R. R. Martin, que é, inclusive, roteirista de alguns episódios. O seriado televisivo ampliou a visibilidade dos livros e foi fundamental para as obras converterem-se em fenômeno de vendas e traduzidos em todo o mundo. Isso explica o fato de A Game of Thrones só ter sido traduzida e publicada no Brasil catorze anos depois da publicação do original (BURLAMAQUE; BARTH, 2016).

Sobre a forma como os alunos investigados conseguiram obter os livros, verificou-se que $50 \%$ foram comprados; $39,7 \%$ foram emprestados por colegas, amigos e familiares; $25 \%$ foram retirados da biblioteca escolar ou pública; $25 \%$ foram recebidos de presente; e $14,7 \%$ foram obtidos mediante outras situações.

A respeito dos alunos já terem assistido às adaptações dos respectivos livros para o cinema ou séries de televisão, verificou-se que $90,5 \%$ responderam sim, e apenas $9,5 \%$ afirmaram não ter ainda assistido nenhuma versão nesse formato.

\section{Gráfico 9 - Adaptações literárias assistidas em filmes ou séries}

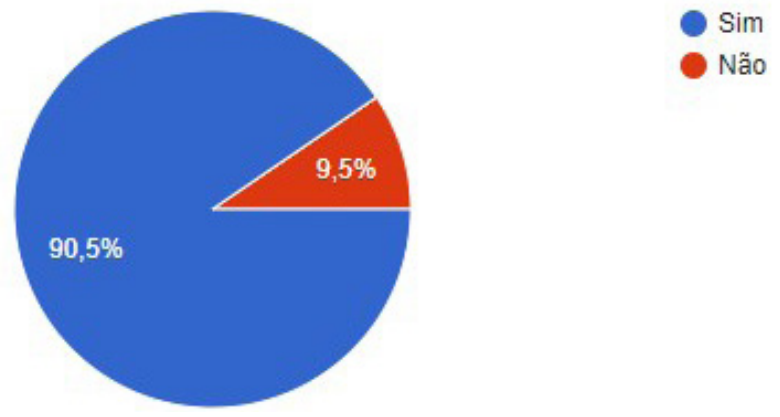

Fonte: Elaborado pela autora. 
Em relação aos livros cujos participantes da pesquisa viram a adaptação para filme ou série, destacou-se que a maioria dos alunos assistiram às sagas Harry Potter, e diversos alunos afirmaram ter visto a versão cinematográfica ou televisiva de todos os livros citados anteriormente, entre muitos outros. Observa-se que 50,7\% assistiram em casa, via TV por assinatura; 45,3\% assistiram no computador ou TV, baixados por meio de programas específicos; $42,7 \%$ assistiram pelo Netflix; 25,3\% em DVDs ou Blu-Rays locados; 21,3\% dos alunos assistiram no cinema.

\section{Gráfico 10 - Onde as adaptações literárias foram assistidas}

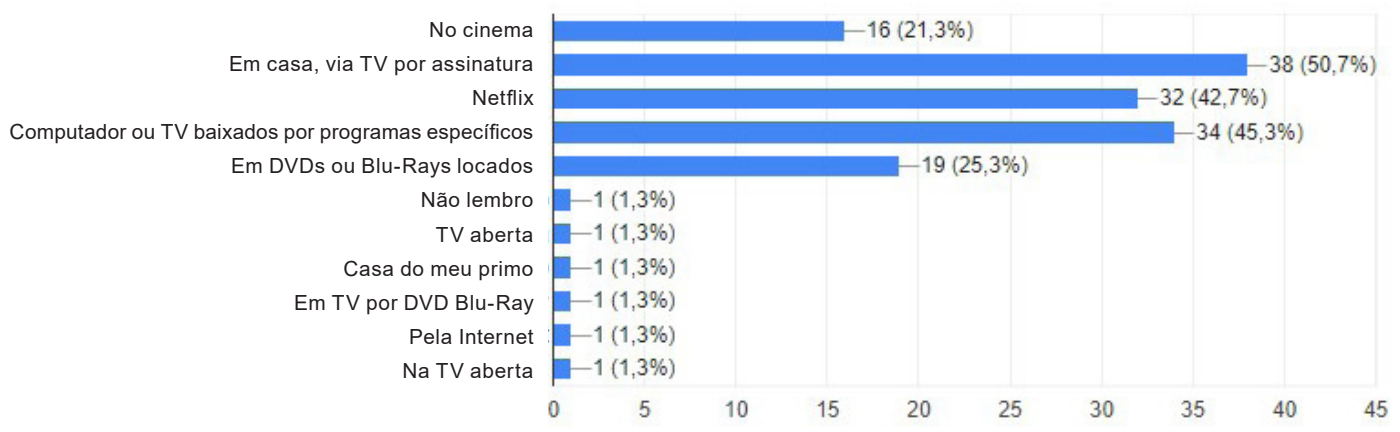

Fonte: Elaborado pela autora.

Ao serem questionados se primeiramente leem ao livro ou assistem ao filme, verificou-se que 7,4\% dos alunos apenas assistiram à adaptação; $11,1 \%$ primeiro leu os textos e, motivados pela leitura, assistiu à adaptação; $18,5 \%$ apenas assistiram à adaptação e não leram o livro; $21 \%$ primeiro assistiram à adaptação e depois leram o livro; $34,6 \%$ em alguns casos primeiro leram o livro e depois assistiram à adaptação, mas em outras situações ocorreu o contrário.

\section{Gráfico 11 - Ordem de consumo entre leitura e adaptação}

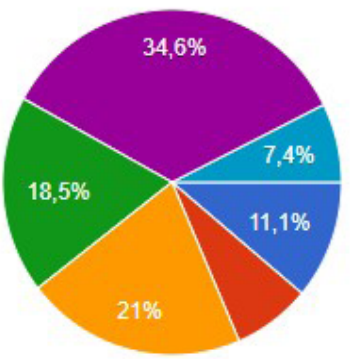

Primeiro leu os textos e, motivado pela leitura, assistiu à adaptação pa.

Apenas leu os livros, mas não chegou a assistir nenhuma adaptação para...

Primeiro assistiu às adaptações para o cinema/ série de televisão e, com..

Apenas assistiu as adaptações para o cinema/ série de televisão, mas não.

Em alguns casos primeiro viu os fil..

Em alguns casos apenas viu os film..

Fonte: Elaborado pela autora.

No que diz respeito ao público possuir os livros mencionados, a partir do gráfico podemos ver que $17,1 \%$ dos alunos costumam adquirir ou ganhá-los, e tem todo o conjunto de livros; $31,7 \%$ compram ou já receberam de presente, mas não tem todo o conjunto de livros; $1,2 \%$ dos participantes, além de terem todos os livros, também tem todos os DVDs/Blu-Rays dos filmes; $4,9 \%$ além de terem alguns livros, também tem alguns DVDs/Blu-Rays dos filmes; 40,2\% não costuma adquirir ou ganhar os livros, mas gostaria; e 15,9\% não tem interesse em possuir tais objetos. 


\section{Gráfico 12 - Costume de adquirir/ganhar de presente os livros indicados}

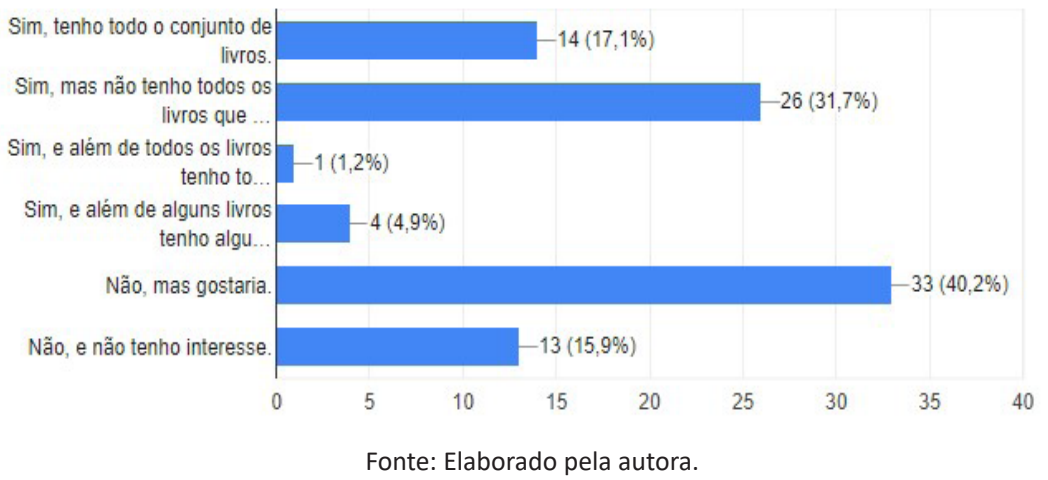

Sobre considerar importante possuir a versão física do livro e/ou filme em mãos, além de outros objetos personalizados que remetem ao universo dos grandes fenômenos literários, verificou-se que $48,8 \%$ responderam que sim; $34,5 \%$ não; enquanto que $16,7 \%$ dos jovens demonstra ser indiferente.

\section{Figura 6 - Jovem leitora usando produtos da saga Harry Potter}

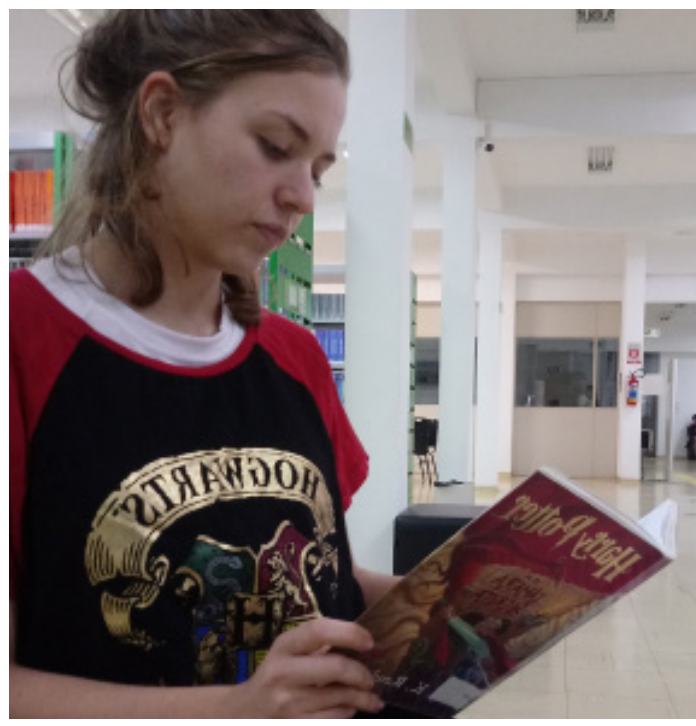

Fonte: Acervo da autora.

\section{Gráfico 13 - Importância de ter a versão física dos livros e filmes/séries, além de objetos personalizados que remetem a seus universos}
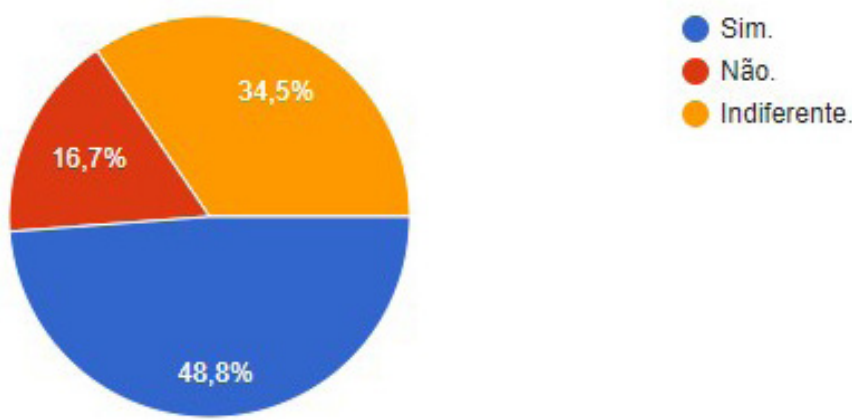

Fonte: Elaborado pela autora.

Quanto às razões dos investigados considerar importante ter o livro, o filme e seus produtos físicos, caso tenham marcado "sim" no questionário, as respostas dos alunos foram variadas. Muitos 
disseram ser importante, porque possuir o objeto físico os faz sentir parte do universo do livro e torna a leitura mais agradável e atrativa. Alguns também falaram que gostam de colecionar os respectivos produtos, entre outros motivos. A respeito dos alunos não achar importante ter o livro, o filme e seus produtos físicos, caso tenham respondido "não" no questionário, verificou-se que eles consideram que, mesmo que seja algo bonito, é desnecessário ou irrelevante, e o importante é ler o livro ou assistir ao filme.

Sagas, de modo geral, são formadas por uma hibridação, que une mitos e elementos da tradição oral e, a partir de uma releitura criativa dos mesmos, os autores normalmente incluem valores considerados importantes para a sociedade contemporânea. Além disso, a mesma história é contada por diferentes sistemas intersemióticos, como se observou a respeito das sagas mais citadas na pesquisa e suas consequentes adaptações em forma dos mais diversos produtos culturais. García Rivera (2004) observa que toda saga cria um paracosmos, ou seja, um mundo próprio, autoconsciente e com regras delimitadas. Nessa direção, o paracosmos de uma saga não se limita a um livro, mas é ampliado para continuações. Da mesma forma, ultrapassa a escrita e abarca diferentes linguagens, como as dos filmes, séries, mapas, games, entre outras. Desse modo um livro pode dar origem a um universo que será expandido em outras plataformas e, muitas vezes, por autores diferentes. Diante desses aspectos, embora concordamos, sobretudo, com Benjamin (1994), Bourdieu $(1983,2009)$ e Canclini $(2008,2015,2016)$, a respeito da apropriação que o capitalismo investe sobre a indústria cultural, convertendo a arte e, neste caso, a literatura em objeto de consumo, é necessário admitir que as sagas literárias e, por consequência, suas adaptações para as mais diversas linguagem e produtos, têm elementos intrínsecos que se comunicam com os valores subjetivos do receptor, os quais, ainda que não explorados nesta pesquisa, são preponderantes para justificar a imersão dos alunos investigados neste universo.

\section{Considerações finais}

O desenvolvimento da pesquisa possibilitou verificar que, entre o público participante, constituído por jovens que se encontram na faixa etária entre 15 a 18 anos, estudantes de uma instituição pública federal, localizada no município de São Borja, o qual se situa na fronteira oeste do estado do Rio Grande do Sul, na divisa com a Argentina, a relação entre a literatura e o consumo cultural se constrói dentro da perspectiva que Canclini (2015, p. 129) nomeia como "as identidades como espetáculo multimídia”. Nesse contexto, é possível questionar a razão que leva jovens que vivem distante de grandes centros urbanos - a considerar que São Borja está localizada uma distância de $584 \mathrm{~km}$ de Porto Alegre e a $865 \mathrm{~km}$ de Buenos Aires - e, consequentemente, não têm acesso na cidade onde vivem a shopping centers ou cinemas a adotarem padrões de consumo cultural, forjados por uma ordem econômica global, a considerar que os textos literários prioritariamente citados na pesquisa, são essencialmente destinados a serem absorvidos pelo mercado.

Podemos afirmar que os dados obtidos, por intermédio da pesquisa, comprovam que a tensão existente entre o regional e o global dissolve-se à medida que verificamos que os jovens sujeitos investigados demonstram claramente ser consumidores potenciais da literatura produzida com $o$ propósito mercadológicos, bem como dos produtos culturais advindos do sucesso das adaptações da maioria dessas sagas literárias para o cinema, produção de séries televisivas, jogos eletrônicos, entre outros produtos de uso cotidiano e colecionáveis.

A instauração do cenário mercadológico mediado pela literatura e voltado ao consumo global é perceptível, tal como observa Canclini em Leitores, espectadores e internautas, ao considerar que se a independência conquistada pelas artes e pela literatura poderia ser apresentada para justificar a autonomia metodológica dos seus estudos, o que tem se observado, há muito tempo, é a tendência para: 
[...] mercantilizar a produção cultural, massificar a arte e a literatura e oferecer os bens culturais com apoio de vários suportes ao mesmo tempo (por exemplo, filmes não só em cinemas, mas também na televisão e em vídeo) tira autonomia dos campos culturais. A fusão de empresas acentua essa integração multimídia e a sujeita a critérios de rentabilidade comercial que prevalecem sobre a pesquisa estética. (CANCLINI, 2008, p. 20).

Diante de tais elementos capazes de amalgamar o dinamismo das sagas literárias que, após lançadas, imediatamente adquirem um elevado percentual de vendas em diversos idiomas, e do contexto tecnológico, que permeia os modos atuais de consumo, permitindo que jovens, mesmo vivendo afastados dos grandes centros urbanos, tenham acesso aos bens disponibilizados pela indústria cultural, facilmente acessados e/ou adquiridos pela Internet, importantes valores relativas à constituição identitária e a educação são colocados em pauta, tal como questiona Canclini (2008, p. 24): "Escolas [...] renovadas, com professores treinados nas novas linguagens e habilidades, ajudariam a discernir o valor da informação e dos espetáculos, passar da conectividade indistinta ao pensamento crítico?"

Conforme Martos García (2009) as sagas fantásticas, normalmente, recebem grandes depreciações críticas de professores, estudiosos e escolas. Os posicionamentos condenatórios se amparam na acusação de que as sagas são histórias superficiais, em virtude de suas narrativas irreais e fantásticas. Martos García admite que, de certa proporção, as sagas, de fato, possibilitam leituras escapistas. Todavia, esse aspecto não precisa ser considerado problemático, mas, ao contrário, a evasão pode se manifestar como uma verdade essencial do mito. Isso significa que a fantasia estabelece um diálogo com a mitologia humana em sua totalidade todo, com a necessidade da fantasia que configura a natureza humana. Dessa forma, de acordo com o autor espanhol, as sagas, provenientes da ficção fantástica, merecem ser lidas e analisadas como instrumentos de racionalidade, capazes de elaborar ilusões ou utopias úteis para a sociedade no contexto do século atual.

Pensamos, diante do posicionamento dos jovens sujeitos da pesquisa que, se por uma perspectiva, a literatura e seus produtos derivados, mediados pela indústria cultural, são incorporados aos seus hábitos de consumo quase que na mesma intensidade com a qual são lançados pelo mercado, sob outro viés, verificou-se que há um expressivo discernimento nas escolhas dos textos a serem lidos, filmes/séries assistidos e produtos adquiridos, amparado pelo gosto, poder aquisitivo ou preceitos críticos que regem o seu comportamento como leitor, espectador e consumidor, o que nos leva a concordar com Lipovetsky (2004, p. 87), ao afirmar que "deve-se melhor 'armar' os jovens e os cidadãos em referências fundamentais a fim de que o divertimento midiático possa ser recebido com distanciamento e liberdade".

\section{Referências}

BENJAMIN. Walter. Magia e técnica, arte e política. Tradução: Sérgio Paulo Rouanet. São Paulo: Brasiliense, 1994.

BLOOM, Harold. Can 35 Million Book Buyers Be Wrong? Yes. The San Francisco Jung Institute Library Journal, San Francisco, v. 19, n. 4, p. 49-51, 2000.

BOURDIEU, Pierre. Gostos de classe e estilos de vida. In: ORTIZ, Renato. Pierre Bourdieu. São Paulo: Ática, 1983. p. $82-121$.

BOURDIEU, Pierre. A economia das trocas simbólicas. São Paulo: Perspectiva, 2009.

BURLAMAQUE, Fabiane Verardi; BARTH, Pedro Afonso. Experiências literárias com sagas fantásticas: As crônicas de gelo e fogo e a criação de um novo universo. Revista Brasileira de Literatura Comparada, Porto Alegre, v. 18, n. 29, p. 1-25, 2016. 
CANCLINI, Néstor García. Leitores, espectadores e internautas. São Paulo: Iluminuras, 2008.

CANCLINI, Néstor García. Consumidores e cidadãos: conflitos multiculturais da globalização. Rio de Janeiro: Editora UFRJ, 2015.

CANCLINI, Néstor García. O mundo inteiro como um lugar estranho. São Paulo: Editora USP, 2016.

DUCROT, Oswald; TODOROV, Tzvetan. Dicionário das ciências da linguagem. Tradução: A. Massano, J. Afonso, M. Carillo e M. Font. Lisboa: Dom Quixote, 1976.

GARCÍA RIVERA, Glória. Paracosmos: las regiones de la imaginación (los mundos imaginarios en los géneros de Fantasía, Ciencia Ficción y Horror: nuevos conceptos y métodos). Primeras notícias: Revista de literatura, n. 207, p. 61-70, 2004.

INSTITUTO PRÓ-LIVRO. Retratos da leitura no Brasil. 5. ed. São Paulo: Instituto Pró-Livro, 2020. Disponível em: https://www.prolivro.org.br/5a-edicao-de-retratos-da-leitura-no-brasil-2/a-pesquisa-5a-edicao/. Acesso em: 16 dez. 2020. LIPOVETSKY, Gilles. Metamorfoses da cultura liberal: ética, mídia e empresa. Porto Alegre: Sulina, 2004.

LOPES, Cristiano Camilo. E o filme gerou o leitor: um estudo sobre as crônicas de Nárnia no Brasil. Teoliterária, São Paulo, v. 7, n. 14, p. 252-275, 2017.

MARTOS GARCÍA, Alberto. Introducción al mundo de las sagas. Badajoz: Editora Universidade de Extremadura, 2009.

NAKAGOME, Patrícia Trindade. FRANCISCO, Beatriz Masson. A massa da literatura: recepção crítica de Harry Potter. Revista Estação Literária, Londrina, v. 13, p. 425-439, jan./jun. 2014.

NOLASCO, Edgar Cézar. Literatura, mercado e consumo. Raído, Dourados, v. 1, n. 1, p. 33-41, jan./jul. 2007.

REIMÃO, Sandra. Mercado editorial brasileiro: 1960-1990. São Paulo: Com-Arte: Editora Fapesp, 1996.

RÉROLLE, Raphaëlle. Tolkien, l'anneau de la discorde. Le Monde, Paris, 5 jul. 2012. Culture. Disponível em: www.lemonde.fr/culture/article/2012/07/05/tolkien-l-anneau-de-la-discorde_1729858_3246.html. Acesso em:7 jan. 2021.

SEMMELMANN, Cristina Casagrande de Figueiredo. Em boa companhia: a amizade em O Senhor dos Anéis. 2017. 249 f. Dissertação (Mestrado em Letras) - Universidade de São Paulo, São Paulo, 2017.

SODRÉ, Muniz. Best-seller: a literatura de mercado. São Paulo: Ática, 1985.

Data de submissão: 04/12/2020

Data de aceite: 13/01/2021 